\title{
Zinc Supply and Root Pruning Responses on Growth and Zinc Absorption of Transplanted Rice (Oryza Sativa L.)
}

\author{
Mulyati $^{1}$ \\ ${ }^{1}$ (Department of Soil Science, Agriculture Faculty, Mataram University)
}

\begin{abstract}
Zinc (Zn) deficiency is the most widespread micronutrient disorder in rice. The objectives of the present study were to investigate the effect of Zn application and root pruning on Zn absorption by transplanted rice. Pots were arranged in a factorial complete randomized design with three replicates, which comprised of 7 rates of $\mathrm{Zn}\left(0,20,40,80,160,320\right.$ and $640 \mu \mathrm{g} \mathrm{Zn} \mathrm{kg}{ }^{-1}$ air dry soil), with 0 and $50 \%$ root pruning. The obtained data were analysed statistically by the analysis of variance. The results showed that the relative $\mathrm{Zn}$ absorption rate were closely related to the dry weight of shoot and root. Root pruning had a lower rates of Zn absorption than those of without pruning. Therefore, root pruning impaired plants growth and eventually reduced dry matter production. In conclusion, root recovery and root function of transplanted rice were sluggish by low Zn supply and root pruning, and increasing Zn application could not compensate for the pruned roots.
\end{abstract}

Keywords: Zinc, root pruning, absorption, transplanted rice

\section{Introduction}

Zinc $(\mathrm{Zn})$ deficiency is recoqnized as one of the most widespread soil constrain in rice production (Arnold et al., 2010). Nutritional disorder of rice associated with micronutrients have escalated as modern technology for rice production has been applied. These include increase crop requirements on the soil's ability to supply $\mathrm{Zn}$, use of urea and phosphate fertilizers which the resulting of P-induced $\mathrm{Zn}$ deficiency (Srivastava et al., 1999). Recent research shows that micronutrients particularly Zn have an important role in root stress (Welch, 1995). Marschner (1993) reviewed that plant roots may also influence the availability and uptake of mineral nutrients by releasing of root exudates, which induce changes in the rhizosphere. The rhizosphere modification of rice roots may be as the important factor in decreasing the concentration and mobility of $\mathrm{Zn}$ in the flooded soil (Marschner, 2002).

Zinc deficiency mostly occurs in flooded rice, because flooded soil causes drastic change in the chemical and biological reaction in the soil (Turner \& Patrick, 1986; Kyuma, 2004). It could be related to the chemical properties of flooded soil which decrease $\mathrm{Zn}$ availability and also attributed to the inefficient $\mathrm{Zn}$ absorption of transplanted rice seedlings. When soil is flooded, the concentration of most nutrients such as phosphorus (P) in the soil solution increases but it decrease in $\mathrm{Zn}$ availability (Tandano \& Yoshida, 1978).

Generally, Zn deficiency is associated with the seedlings development stage of growth at 15 to 20 days after seedlings emergence (Wells et al., 1993). Therefore, rice seedlings appear to be sensitive to Zn deficiency after transplanting into flooded soil. Flooded soil reduces most of plants growth by affecting physiological processes such as decrease in absorption and transport ions through roots. It may cause plants suffer from nutrient deficiency, because translocation of the nutrients from roots to the shoots is often restricted by lack of aeration (Huang et al., 1995). Zinc deficiency can be corrected by applying Zn compounds to the soil or transplanted wetland rice seedlings for further growth especially in the critical early growth stage (QuijanoGuerta et al., 2002). A small amount of Zn apply to the nursery may be feasible, effective and efficient for uptake nutrients (Shuman and Wang, 1997).

Seedlings are pulled up from the nursery without regard to the amount of roots that are retained on each plant (Grist, 1975). Previous study showed that transplanted crop such as oilseed rape or canola has a higher external Zn requirement compare to direct sown plant (Mulyati et al., 1997). In addition, Mulyati et al. (2005) reported that seedbed $\mathrm{Zn}$ nutrition influence the early growth of transplanted oilseed rape. Jack (1923) cited Grist (1975) stated that the physiological factors involved in transplanting are obscure, the damage of the root system at transplanting or root pruning would stimulate the plant growth and. The mechanisms of rice growing in flooded soil after transplanting and their nutrients absorption especially for $\mathrm{Zn}$ is poorly understood. Therefore, it is worthy to investigate the effect of $\mathrm{Zn}$ supply and root pruning on the growth of transplanted rice in relation to the relative $\mathrm{Zn}$ absorption rate, in order to overcome the recovery of root function.

The purposes of the present study were to investigate the effect of $\mathrm{Zn}$ application and root pruning on the vegetative growth stage of transplanted rice; and also to determine the relative $\mathrm{Zn}$ absorption rate by transplanted rice with $50 \%$ root had been pruned and without pruning. 


\section{Materials and methods}

Treatment. A pot experiment conducted in a trace-element glasshouse. Rice seedlings treated with seven rates of $\mathrm{Zn}$ supplied as $\mathrm{ZnSO}_{4} 7 \mathrm{H}_{2} \mathrm{O}$, respectively : 0, 20, 40, 80, 160, 320 and $640 \mu \mathrm{g} \mathrm{Zn} \mathrm{kg}{ }^{-1}$ air dry soil, and root pruning ( $0 \%$ pruning or without pruning and $50 \%$ of root pruning). Each treatment combination comprised of three replications. Pots were arranged in a Factorial Randomized Block Design.

Seedling growth. The rice cultivar (cv) was used IR-36 Rice seeds dormancy was broken by heating seeds at $35{ }^{\circ} \mathrm{C}$ for 24 hours. Seeds were placed for 48 hours on brown filter paper moistened with $1 \mathrm{mM} \mathrm{CaSO}_{4}$ and 10 $\mu \mathrm{M} \mathrm{H}_{3} \mathrm{BO}_{3}$ solution at room temperature to initiate germination. Seeds were sown in a seedbed by using sand culture. Before sowing, the sand were rinsed in DDI water. Complete nutrients were applied into the seedbed soil including $50 \mu \mathrm{g} \mathrm{Zn} \mathrm{kg}^{-1}$ air dry soil to provide adequate nutrients for seedling growth. Rice seeds were raised in a seedbeds for 24 days before being transplanted into $\mathrm{Zn}$ treated soils.

Plant culture. Representative soil were collected from the field on $0-20 \mathrm{~cm}$ depth. Air dried soil were sieved through a stainless steel screen $(4 \mathrm{x} 4 \mathrm{~mm})$ and mixed, then placed in $5 \mathrm{~kg}$ portions of air dry soil the plastic bags fitted inside plastic pots. All treatments were receive basal nutrients as follow : $174 \mathrm{~K}_{2} \mathrm{SO}_{4}, 98 \mathrm{CaCl}_{2}$ $2 \mathrm{H}_{2} \mathrm{O}, 93 \mathrm{NH}_{4} \mathrm{NO}_{3}, 90.7 \mathrm{KH}_{2} \mathrm{PO}_{4}, 24.6 \mathrm{MgSO}_{4} .7 \mathrm{H}_{2} \mathrm{O}, 8.5 \mathrm{MnSO}_{4} .7 \mathrm{H}_{2} \mathrm{O}, 1.3 \mathrm{CuSO}_{4} .5 \mathrm{H}_{2} \mathrm{O} \quad 0.85 \mathrm{H}_{3} \mathrm{BO}_{3}$, and $0.4 \mathrm{NaMoO}_{4} 2 \mathrm{H}_{2} \mathrm{O} \mathrm{mg} \mathrm{kg}{ }^{-1}$ air dry soil. The macronutrients were purified to remove $\mathrm{Zn}$ by using dithizone in chloroform at pH 6.5 to 7.5 (Hewitt, 1966). The nutrient solutions were added to the soil and mixed thoroughly, then watered until flooded to $3-5 \mathrm{~cm}$ above the level of the soil surface. Soil in each pot was paddled for 2 weeks before transplanting.

Six selected seedlings were transplanted into each pot. At 7 days after transplanting (DAT), seedlings were thinned to 3 plants per pot. Seedlings sampled at thinning were weight for fresh and dry weight, and also used for $\mathrm{Zn}$ determination. Transplanting were done gently, then carefully pull away for one by one plant. The soil was maintained at flooded condition $(3-5 \mathrm{~cm})$ throughout the experiment with double deioned water (DDI) water, every week $280 \mathrm{NH}_{4} \mathrm{NO}_{3} \mathrm{mgkg}^{-1}$ were applied to each pot. Pots were maintained in temperature controlled water baths at $28-30{ }^{\circ} \mathrm{C}$.

Harvest procedure. Rice seedlings growth was measured 30 DAT. Plants were cut at ground level $(1 \mathrm{~cm}$ from the soil surface) as shoot and root samples were washed carefully to remove soil with DDI water. Fresh and dry weight of shoots and roots were recorded. After that, all plant samples were oven dried at $65-70{ }^{\circ} \mathrm{C}$ until constant weight achieved. Root length was measured by using Comair root length scanner (Newman, 1966).

Plants and soil analysis. The plant samples were milled for analysis. Zinc concentration was determined after digesting samples in concentrated $\mathrm{HNO}_{3}$ at $135-140{ }^{\circ} \mathrm{C}$ by using an inductively couple plasma - optical emission spectrometry (ICP-OES) (Zarcinas et al., 1987).

Data analysis. Collected data from the experiment were analysed statistically by using analysis of variance, When F-values were significant at $\mathrm{P} \leq 0.05$, means comparison among treatments were compared by employing Fisher's least significant difference.

\section{Zinc Responses on the Growth}

\section{Results and Discussion}

These visible symptoms of $\mathrm{Zn}$ deficiency observed at 12 days after transplanting, with absence of $\mathrm{Zn}$ and low Zn supply ( $20 \mu \mathrm{g} \mathrm{Zn} \mathrm{kg}{ }^{-1}$ soil), and mild symptoms at 40 also $\mu \mathrm{g} \mathrm{Zn} \mathrm{kg}{ }^{-1}$ soil. It occurred both in plant with root had been pruned or root damaged and without pruning or intact root system. Zn deficiency symptoms marked by yellowing and had brown spot on the young and old leaf blades. Young leaves became chlorotic, bronzing of the leaves, internodes short, plants became dwarf, produced few tillers and new leaves were formed smaller than plants supplied with adequate $\mathrm{Zn}$, plants growth were retarded. As a result, plants produced lower root and shoot dry matter. While, plants supplied with $80 \mu \mathrm{g} \mathrm{Zn} \mathrm{kg}^{-1}$ soil or higher did not show any of visible sign of $\mathrm{Zn}$ deficiency symptoms.

Shoot and root dry matter production responded positively $(\mathrm{P} \leq 0.05)$ by $\mathrm{Zn}$ application and root pruning, no interactive effect was found between $\mathrm{Zn}$ supply and root pruning (Table 1). Without $\mathrm{Zn}$ supply and low $\mathrm{Zn}$ supply and combination with $50 \%$ root pruning were strongly depressed shoot dry weight. Root dry matter responded to increasing $\mathrm{Zn}$ supply in similar way to shoot dry matter. These fenomenons were indeed due to $\mathrm{Zn}$ deficiency was evident from a reduction of relative $\mathrm{Zn}$ absorption per rice plant.

The maximum shoot dry matter was obtained at $40 \mu \mathrm{g} \mathrm{Zn} \mathrm{kg}^{-1}$ soil, and at 40 to $160 \mu \mathrm{g} \mathrm{Zn} \mathrm{kg}{ }^{-1}$ soil shoot dry matter exhibited a plateau, and no significant difference was found between zinc added 160 and 640 $\mu \mathrm{g} \mathrm{Zn} \mathrm{kg}{ }^{-1}$ soil. Indeed, raising $\mathrm{Zn}$ supply from 40 to $640 \mu \mathrm{g} \mathrm{Zn} \mathrm{kg}^{-1}$ soil had no significant effect on the shoot growth. Thus, this suggests that rice plant had a lower functional requirement of $\mathrm{Zn}$ for the growth and development. In addition, root pruning resulted in reduced the dry matter production, and increasing of $\mathrm{Zn}$ application could not compensate for the pruned root (Bar-Tal et al., 1994). 
Table 1. Effect of zinc supply and root pruning on shoot dry weights (g plant ${ }^{-1}$ ) of rice cv. IR-36 at 15 and 30 days after transplanting

\begin{tabular}{|c|c|c|c|}
\hline \multicolumn{2}{|l|}{ Treatment } & \multicolumn{2}{|c|}{ Dry weights (g plant ${ }^{-1}$ ) } \\
\hline $\begin{array}{c}\text { Zinc level } \\
\left(\mu \mathrm{g} \mathrm{kg}^{-1}\right)\end{array}$ & $\begin{array}{l}\text { Root pruning } \\
(\%)\end{array}$ & Shoot & Root \\
\hline \multirow[t]{2}{*}{0} & 0 & $2.20 \pm 0.22$ & $1.17 \pm 0.03$ \\
\hline & 50 & $2.10 \pm 0.20$ & $0.81 \pm 0.09$ \\
\hline \multirow[t]{2}{*}{20} & 0 & $2.91 \pm 0.06$ & $1.19 \pm 0.03$ \\
\hline & 50 & $2.77 \pm 0.30$ & $0.93 \pm 0.07$ \\
\hline \multirow[t]{2}{*}{40} & 0 & $3.03 \pm 0.26$ & $1.23 \pm 0.09$ \\
\hline & 50 & $3.01 \pm 0.11$ & $0.96 \pm 0.04$ \\
\hline \multirow[t]{2}{*}{80} & 0 & $3.12 \pm 0.10$ & $1.24 \pm 0.18$ \\
\hline & 50 & $3.10 \pm 0.04$ & $0.97 \pm 0.03$ \\
\hline \multirow[t]{2}{*}{160} & 0 & $3.26 \pm 0.04$ & $1.27 \pm 0.19$ \\
\hline & 50 & $3.25 \pm 0.13$ & $0.98 \pm 0.06$ \\
\hline \multirow{2}{*}{320} & 0 & $3.29 \pm 0.16$ & $1.29 \pm 0.10$ \\
\hline & 50 & $3.21 \pm 0.12$ & $1.00 \pm 0.09$ \\
\hline \multirow[t]{2}{*}{640} & 0 & $3.37 \pm 0.03$ & $1.31 \pm 0.07$ \\
\hline & 50 & $3.20 \pm 0.05$ & $1.02 \pm 0.07$ \\
\hline
\end{tabular}

Values are means of three replicates \pm SE.

Root dry matter production increased progressively by $\mathrm{Zn}$ supply and root pruning. Zinc supply from 0 to $20 \mu \mathrm{g} \mathrm{Zn} \mathrm{kg}^{-1}$ did not increased root dry matter production. The maximum root dry matter was attained at 80 $\mu \mathrm{g} \mathrm{Zn} \mathrm{kg}{ }^{-1}$ soil. Thus, shoot growth of transplanted rice required a higher external $\mathrm{Zn}$ requirement compared with root growth. This result was similar to previous study on transplanted oilseed rape (Mulyati, 2004). Root growth and development are characterised by a complex interaction between roots and shoots, and between roots and the environment (Marschner, 1993; Marschner, 2002). These present study indicated that the maximum shoot growth required a higher external $\mathrm{Zn}$ supply compared with root growth. At the early growth stage, root and shoot growth required the same level of $\mathrm{Zn}$ supply. Zinc requirement for shoot growth increased to $160 \mu \mathrm{g} \mathrm{Zn} \mathrm{kg}^{-1}$ soil exceeded that $\mathrm{Zn}$ requirement for root growth. Plants with low $\mathrm{Zn}$ added and without $\mathrm{Zn}$ added were significantly depressed root and shoot dry matter both in root had been pruned and without root had been pruned. These result confirmed that the higher external $\mathrm{Zn}$ requirement for transplanted rice is due to the requirement for shoot growth rather than root growth (Mulyati, 2009). It has been well accepted that root system such as root diameter, size, volume and length are crucial factors in determining plant growth and crop yield through nutrients uptake and water (Morita and Abe, 1996; Yamauchi et al., 1996). Increasing Zn supply and $50 \%$ root pruning had a significant effect on shoot: root ratio (Figure 1). For adequate $\mathrm{Zn}$ supply and high $\mathrm{Zn}$ supply shoot: root ratio tended to be stable (consistent). The removal of $50 \%$ roots produced higher shoot : root ratio than that of plants with root had not been pruned. It apparent that root

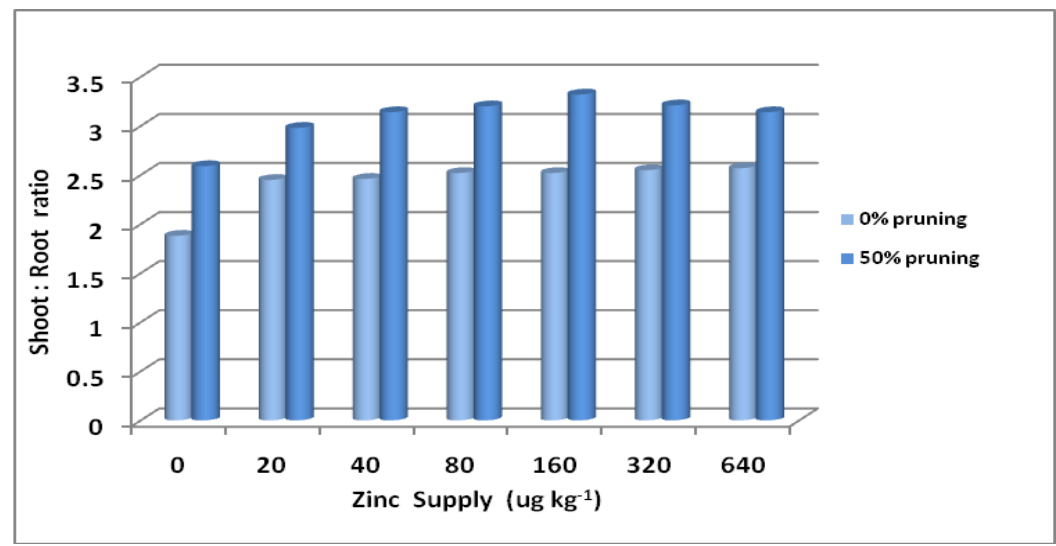

Figure 1. Effect of zinc supply and root pruning on shoot: root ratio of transplanted rice at harvest days.

pruning would have removed a significant portion of root absorbing surface, leading to the increased of external $\mathrm{Zn}$ requirement for $\mathrm{Zn}$ absorption during the post-transplanting period before the full recovery of root function. Thus, the damage of root system of transplanted rice required a period of time for the root recovery to re-establish a favourable shoot: root ratio. Plants with root had been pruned decreased with time, but plants with root had not been pruned were almost un-change, except for low Zn supply or between 20 and $40 \mu \mathrm{g}$ $\mathrm{Zn} \mathrm{kg}^{-1}$ and without $\mathrm{Zn}$ added. Plant with root damaged had higher shoot: root ratio than those of intact root system. The shoot: root ratio induced by root pruning led to impaired the recovery of root function required higher external $\mathrm{Zn}$ requirement. 


\section{Root length development}

Increasing $\mathrm{Zn}$ supply from 0 to $80 \mu \mathrm{g} \mathrm{Zn} \mathrm{kg}^{-1}$ soil increased $(\mathrm{P} \leq 0.05)$ root length by $10 \%$ at the harvest day or 30 days after transplanting. There was a significant interaction between $\mathrm{Zn}$ supply and root pruning (Table 2). Plants with root had not pruned showed a greater $(\mathrm{P} \leq 0.05)$ root length development about $15 \%$ than plants with root have not been pruned. From this observation, it appeared that shoot growth was more correlated with the response of root length. As for shoot dry weight, the maximum root length also required a higher external $\mathrm{Zn}$ requirement compared with root dry matter, the greater the root length development the larger shoot dry matter were obtained. These observation was consistent with the result reported by Barber and Silberbush (1984) on the root system of rice which is constitute by their root morphology such as diameter, length and branching.

Table 2. Effect of zinc supply and root pruning on the root length development of transplanted rice

\begin{tabular}{|c|c|c|}
\hline \multicolumn{2}{|l|}{ Treatment } & \multirow{2}{*}{$\begin{array}{l}\text { Root length } \\
\left(\mathrm{m} \text { plant } \mathrm{t}^{-1}\right)\end{array}$} \\
\hline Zinc level $\left(\mu \mathrm{g} \mathrm{kg}^{-1}\right)$ & Root pruning (\%) & \\
\hline \multirow[t]{2}{*}{0} & 0 & $4.7 \pm 0.1$ \\
\hline & 50 & $1.2 \pm 0.2$ \\
\hline \multirow[t]{2}{*}{20} & 0 & $6.3 \pm 0.1$ \\
\hline & 50 & $4.6 \pm 0.1$ \\
\hline \multirow[t]{2}{*}{40} & 0 & $7.4 \pm 0.1$ \\
\hline & 50 & $6.4 \pm 0.3$ \\
\hline \multirow[t]{2}{*}{80} & 0 & $8.5 \pm 0.1$ \\
\hline & 50 & $6.9 \pm 0.2$ \\
\hline \multirow[t]{2}{*}{160} & 0 & $9.6 \pm 0.1$ \\
\hline & 50 & $7.4 \pm 0.2$ \\
\hline \multirow[t]{2}{*}{320} & 0 & $9.2 \pm 0.2$ \\
\hline & 50 & $8.0 \pm 0.1$ \\
\hline \multirow[t]{2}{*}{640} & 0 & $9.1 \pm 0.2$ \\
\hline & 50 & $8.4 \pm 0.2$ \\
\hline
\end{tabular}

Values are means of three replicates \pm SE.

\section{Relative Zn absorption rate}

Rate of $\mathrm{Zn}$ absorption per unit root fresh weight generally increased with increases in the external $\mathrm{Zn}$ supply both with root had been pruned or had not been pruned, but no interactive was found between the treatment (Table 3). The relative $\mathrm{Zn}$ absorption rate in plants with root had been pruned were slightly higher than plants with intact root systems. Increasing $\mathrm{Zn}$ supply from 0 to $40 \mu \mathrm{g} \mathrm{Zn} \mathrm{kg}{ }^{-1}$ soil increased rates of $\mathrm{Zn}$ absorption, in addition, increase $\mathrm{Zn}$ supply from 40 to $640 \mu \mathrm{g} \mathrm{Zn} \mathrm{kg}{ }^{-1}$ tended to increase $\mathrm{Zn}$ absorption rates but decreased the effectiveness. These means the average of relative $\mathrm{Zn}$ absorption tended to remain constant over the four weeks successive weeks of growth period. The dry matter production and yield would not simply determined by the quantity of root, but also influence by the morphological aspect and physiological function of root such as the efficiency of root to absorb water and nutrient from soil (Barber and Silberbush, 1984 ; Iwama and Yamaguchi 1996).

Table 3. Effect of zinc supply and root pruning on relative zinc absorption rate in shoot and root $\left(\mu \mathrm{g}\right.$ plant $\left.{ }^{-1}\right)$ of transplanted rice

\begin{tabular}{|c|c|c|c|}
\hline \multicolumn{2}{|l|}{ Treatment } & \multirow{2}{*}{$\begin{array}{l}\text { Shoot } \\
\left(\text { ug plant }^{-1}\right)\end{array}$} & \multirow{2}{*}{$\begin{array}{l}\text { Root } \\
\left(\mu \mathrm{g} \text { plant }^{-1}\right)\end{array}$} \\
\hline Zinc level $\left(\mu \mathrm{g} \mathrm{kg}^{-1}\right)$ & Root pruning (\%) & & \\
\hline \multirow[t]{2}{*}{0} & 0 & $32.9 \pm 2.2$ & $15.4 \pm 1.4$ \\
\hline & 50 & $25.1 \pm 2.2$ & $9.3 \pm 0.5$ \\
\hline \multirow[t]{2}{*}{20} & 0 & $53.4 \pm 1.2$ & $18.2 \pm 2.2$ \\
\hline & 50 & $36.3 \pm 2.3$ & $13.9 \pm 0.2$ \\
\hline \multirow[t]{2}{*}{40} & 0 & $64.2 \pm 3.7$ & $22.7 \pm 0.9$ \\
\hline & 50 & $52.5 \pm 1.3$ & $15.6 \pm 0.3$ \\
\hline \multirow[t]{2}{*}{80} & 0 & $79.5 \pm 2.4$ & $25.4 \pm 2.1$ \\
\hline & 50 & $74.3 \pm 5.7$ & $17.0 \pm 0.1$ \\
\hline \multirow[t]{2}{*}{160} & 0 & $107.8 \pm 2.8$ & $30.4 \pm 1.4$ \\
\hline & 50 & $88.9 \pm 3.7$ & $18.1 \pm 0.2$ \\
\hline \multirow[t]{2}{*}{320} & 0 & $134.0 \pm 4.0$ & $35.5 \pm 0.1$ \\
\hline & 50 & $78.3 \pm 2.9$ & $25.4 \pm 0.1$ \\
\hline \multirow[t]{2}{*}{640} & 0 & $125.6 \pm 1.4$ & $36.7 \pm 1.7$ \\
\hline & 50 & $114.2 \pm 2.6$ & $35.4 \pm 1.6$ \\
\hline
\end{tabular}

Values are means of three replicates \pm SE. 
Notwithstanding, there has rarely been study focus on the optimum size of root required to maximise dry weight production with adequate absorption of water and nutrients particularly $\mathrm{Zn}$. The effect of root pruning has been reviewed by Geisler and Ferree (1984), they reported that root pruning reduced vegetative growth in a number of plant species such as apple, and also affected the early growth of transplanted crops (Mulyati, 2004). The removal of $50 \%$ the root system will lower the growth rate of the shoot, and change in the availability of photosynthesis products, consequently the decline of photosynthesis product led to decreased of shoot and root weights. Indeed, post-transplanting growth of rice may vary with the period time for the root recovery phase, which influence with the environmental factors condition such as soil $\mathrm{pH}$, soil temperature, soil water, waterlogging, nutrient availability and also plant factors including nutrients status of the seedling and seedling vigour.

\section{Conclusions}

This study has imply that zinc application and root pruning of transplanted rice required external $\mathrm{Zn}$ requirement not only for the root growth, but also for the shoot growth and root length development. Apparently, root pruning impaired growth rates and eventually reduced shoot and root dry matter production. Plant with $50 \%$ root had been pruned reduced the shoots and roots of dry matter of transplanted rice, which decreased the relative $\mathrm{Zn}$ absorption rate. It can be concluded that root recovery and root function of transplanted rice were sluggish by low $\mathrm{Zn}$ supply and root pruning.

These results suggest that $\mathrm{Zn}$ supply should be applied to the nurseries, in order to obtain the vigorous seedlings to enhance the earlier establishment in the main-field; and need to be explored further by studying the mechanism of root recovery of transplanted rice or by different plant species.

\section{References}

[1]. Huang, B., J.W. Johnson, D.S NcSmith and D.C. Bridges. 1995. Nutrient accumulation and distribution of wheat genotypes in response to waterlogging and nutrient supply. Plant and Soil. 173:47-54.

[2]. Iwama, K. and J. Yamaguchi. 1996. Difference in root system development among crop species and genotypes. In Root and Nitrogen in Cropping Systems of the Semi-Arid Tropics. Eds. O. Ito, K. Katayama, C. Johansen, J.V.D.K. Kumar Rao, J.J. AduGyamfi and T.J. Rego. Japan International Research Center for Agricultural Science (JIRCAS). No. 3:173-184.

[3]. Geisler, D. and D.C. Ferree. 1984. The influence of root pruning on water relations, net photosynthesis, and growth of young 'Golden Delicious' apple trees. J. Amer. Soc. Hort. Sci. 109 (6): 827-831.

[4]. Morita, S. and J. Abe. 1996. Development of root systems in wheat and rice. $\underline{I n}$ Root and Nitrogen in Cropping Systems of the Semi-Arid Tropics. O. Ito, K. Katayama, C. Johansen, J.V.D.K. Kumar-Rao, J.J. Adu-Gyamfi and T.J. Rego (Eds.). Japan International Research Center for Agricultural Science (JIRCAS). No. 3: 185 -209.

[5]. Mulyati, R. W. Bell, L. Huang. 1997. Evidence that transplanted oilseed rape (Brassica napus L.) has a higher external Zinc requirement than direct sown plants. In : Ando T, Matsumoto H, Mori S, Sekiya J (eds) Plant nutrition - for sustainable food production and environment, Tokyo, Japan. Developments in plant and soil sciences, 78 : 275-276. Kluwer, Dondrecht.

[6]. Mulyati, R. W. Bell, L. Huang. 2005. Seedbed Zinc nutrition affects the early growth of transplanted oilseed rape in chelatebuffered nutrient solution. In : Li C.J et al (ed) Plant nutrition for food security, human health and environmental protection. Beijing, China, pp $898-899$.

[7]. Mulyati, R. W. Bell, L. Huang. 2009. Root Pruning and Transplanting Increase Zinc Requirements of Canola (Brassica napus). Plant and Soil. 314: 11-24.

[8]. Newman, E.I. 1966. Method of estimating the total length of root in a sample. J. Appl. Ecol. 3: 139-145.

[9]. Quijano-Guerta, C., G.J.D. Kirk, A.M. Portugal, V.I. Bartolome and G.C. McLaren. 2002. Tolerance of rice germplasm to zinc deficiency. Field Crop Research. 76: 123 - 130. Elsevier.

[10]. Sillanpää, M. 1990. Micronutrients assessment at the country level: An International Study. FAO Soils Bulletin. No. 63. Food and Agricultural Organization of the United Nation. Rome. Italy.

[11]. Srivastava, P.C., M.S. Gangwar and V. P. Singh. 1999. Adsorption-desorption of zinc in Mollisols and their relationship with uptake of fertilizer-applied zinc by rice. Commun. Soil Sci. Plant Anal. 30(3 \& 4) : 471-481.

[12]. Welch, R.M. 1995. Micronutrient nutrition of plants. In Critical Review in Plant Science. 14(1): 49-82.

[13]. Yamauchi, A., J.R. Pardales and Y. Kono. 1996. Root system structure and its relation to stress tolerance. In Root and Nitrogen in Cropping Systems of the Semi-Arid Tropics. O. Ito, K. Katayama, C. Johansen, J.V.D.K. Kumar Rao, J.J. Adu-Gyamfi and T.J. Rego (Eds.). Japan International Research Center for Agricultural Science (JIRCAS). No. 3 : 211-233.

[14]. Zarcinas, B A., B. Cartwrightand and L R Spouncer. 1987. Nitric acid digestion and multielement analysis of plant material by inductively couple plasma spectrometry. Comm. Soil Sci. Plant Analysis. 18: 131-146.

[15]. Grist, D.H. 1975. Rice. Fifth edition. Whitstable Litho Ltd. Kent.

[16]. Kyuma, K. 2004. Paddy Soil Science. Kyoto University Press (Japan) and Trans Pacific Press (Australia). 279 p.

[17]. Marschner, H. 1993. Zinc uptake from soils. pp. 59-77. In Zinc in Soil and Plants. A.D. Robson (Ed). Kluwer Academic Publishers. London.

[18]. Marschner, H. 2002. Mineral nutrition of higher plants. Second edition. Academic Press. 889 p.

[19]. Rayes, R.Y. and R. Brinkman. 1968. Some methods to minimize zinc deficiency in tranplanted wetland rice. IRRI. Manila. Philippines. pp. 646-655.

[20]. Tadano, T. and S. Yoshida. 1978. Chemical changes in submerged soils and their effects on rice growth. In Soil and Rice. Ed. International Rice Research Institute. pp 399-420. International Rice Research Institute, Los Banos, Philippines.

[21]. Turner, F.T. and W. H. Patrick. 1986. Chemical changes in waterlogged soils as result of oxygen depletion. 9 th. International Congres of Soil Science. Adelaide. Australia.

[22]. Wells, B. R., B.A. Hueyand and R. J. Norman. 1993. Rice. In Nutrient Deficiencies and Toxicities. pp. 15-19. W. F. Bennett (Ed.). The Am. Phyto. Soc. APS Press. St.Paul, Minnesota.USA. 
[23]. Arnold, T, J. Guy, D. Kirk, M. Wissuwa, M. Frei, F.J. Zhao, T.F.D. Mason and D.J. Weiss. 2010. Evidence for the mechanism of zinc uptake by rice using isotope fractionation. Pant Cell \& Environment, 33: 370 - 381.

[24]. Barber, S.A. and M. Silberbush. 1984. Plant root morphology and nutrient uptake. In Root, Nutrient and Water Influx, and Plant Growth. Eds. S.A. Barber and D.R. Bouldin. Amer. Soc. Agron. 49:65-87.

[25]. Bar-Tal, A., A. Feigin, I. Rylski, and E. Pressman. 1994. Effect of root pruning and N-NO 3 solution concentration on nutrient uptake and transpiration of tomato plants. Scientia Horticulturae 58: 77-90.

[26]. Mulyati, 2004. Zinc requirements of transplanted oilseed rape. Ph.D Thesis. Murdoch University. WA. Australia. 